\title{
Teaching Media in the Teaching of Arabic Language/ Media Pembelajaran dalam Pembelajaran Bahasa Arab
}

\author{
Damar Gemilang \\ Institut Agama Islam Negeri Surakarta \\ damargemilang@gmail.com \\ Hastuti Listiana \\ Institut Agama Islam Negeri Surakarta \\ Hastutilistiana11@gmailcom
}

\begin{abstract}
This article discusses the media of learning Arabic language, through library studies that focus on distributing material effectively to students without making them boring. The limited creations and variations in learning as well as the low ability of Arabic language maharah of students make the role of the media so important. The selection of media correctly, can improve the mastery of material skills, motivate, and stimulate students. Through library studies from journals, papers, and books on learning media for the Arabic curriculum which are then analyzed and concluded data will be obtained about learning media for the Arabic curriculum which is useful for teachers. There are several rules in determining the media that will be used by taking into account the direction and objectives of learning, types of learning strategies, understanding the characteristics of the media by the teacher, in terms of cost suitability, media readiness, quality, and environment to operate the media. In terms of functions related to sensing devices, the media are divided into visual media, audio media, and audiovisual media. Meanwhile, viewed from the viewpoint in Arabic and that maharah, the media can be grouped into learning media mufrodat, nahwu-shorof, and Arabic language skills consisting of media istima', qiro'ah, kitabah, and kalam. This can help academics in applying media correctly in the learning of the Arabic language curriculum.
\end{abstract}

Keywords: Media, Learning, Arabic Language

\begin{abstract}
ABSTRAK
Artikel ini membahas mengenai media pembelajaran bahasa Arab, melalui studi kepustakaan yang berfokus untuk menyalurkan materi secara efektif kepada peserta didik tanpa membuatnya merasa bosan. Terbatasnya kreasi dan variasi dalam pembelajaran serta kemampuan maharah bahasa Arab dari peserta didik yang rendah menjadikan peran media begitu penting. Pemilihan media yang tepat dapat meningkatkan penguasaan materi kemahiran, memotivasi, serta menstimulasi peserta didik. Melalui studi kepustakaan dari jurnal, makalah, dan buku mengenai media pembelajaran kurikulum bahasa Arab yang kemudian dianalisis dan disimpulkan akan diperoleh data mengenai media pembelajaran kurikulum bahasa Arab yang berguna untuk guru. Terdapat beberapa aturan dalam menentukan media yang akan digunakan dengan memperhatikan arah dan tujuan pembelajaran, jenis strategi pembelajaran, pemahaman karakteristik media oleh guru, segi kesesuaian biaya, kesiapan medianya, kualitas, dan lingkungan untuk mengoperasikan media tersebut. Dilihat dari segi fungsi yang berhubungan dengan alat penginderaan, media
\end{abstract}


dibagi menjadi media visual, media audio, dan media audio visual. Sedangkan, dilihat dari pandangan dalam berbahasa arab dan maharahnya, media dapat dikelompokkan menjadi media pembelajaran mufrodat, nahwu-shorof, dan keterampilan berbahasa Arab yang terdiri dari media istima', qiro'ah, kitabah, dan kalam. Hal tersebut dapat membantu para akademisi dalam menerapkan media yang tepat dalam pembelajaran kurikulum bahasa Arab.

Kata kunci: Media, Pembelajaran, Bahasa Arab

\section{PENDAHULUAN}

Pada era sekarang, bahasa Arab tidak hanya dipelajari di pondok-pondok pesantren, namun lembaga-lembaga sekolah seperti Madrasah Ibtidaiyah, Madrasah Tsanawiyah dan Madrasah Aliyah juga sudah tidak asing lagi dengan mata pelajaran bahasa Arab. Dalam kegiatan belajar mengajar terdapat komponen-komponen yang saling berinteraksi dan berpengaruh untuk mencapai suatu tujuan pembelajaran. Salah satu komponen pembelajaran yang berperan penting adalah media (Aminudin, 2014: 16). Menurut Abdul Hadi (2011: 5), media merupakan segala hal yang menjadi perantara dalam berlangsungnya proses belajar mengajar yaitu dengan menyalurkan informasi ke penerima.

Penggunaan media dapat mempermudah peserta didik dalam mempelajari suatu materi pelajaran, sehingga proses belajar mengajar menjadi lebih efektif dan efisien, lebih mudah dipahami, menyenangkan, hemat waktu dan energi, serta memberikan hasil belajar yang lebih mendalam (Oemar Hamalik, 2007: 51). Dengan kata lain, hal tersebut sejalan dengan apa yang dinyatakan oleh Rosyidi (2009: 28), bahwa media pembelajaran berguna dalam menunjang proses belajar dan pengajaran agar suatu materi yang diberikan dapat tersampaikan pada peserta didik secara efektif dan lebih mudah diterima tanpa membuat peserta didik merasa bosan. Berdasarkan uraian tersebut dapat disimpulkan bahwa media pembelajaran sangat berpengaruh dan berperan penting dalam keberhasilan kegiatan belajar peserta didik.

Media pembelajaran memiliki pengaruh yang positif terhadap siswa, seperti yang dikemukakan oleh Arsyad (2014: 19), bahwa penggunaan media dalam pembelajaran dapat meningkatkan motivasi, semangat, dan rasa ingin belajar pada peserta didik. Selain itu, hal yang perlu diperhatikan adalah bagaimana memilih media yang tepat dan berkaitan dengan tujuan pembelajaran, hal tersebut dilakukan agar pembelajaran dapat berjalan secara efektif dalam meningkatkan prestasi peserta didik. Dalam rangka 
memaksimalkan penggunaan media pembelajaran kurikulum bahasa Arab yang bermakna bagi siswa, guru dituntut agar dapat mengembangkan dan mengoptimalkan media yang digunakan sesuai dengan tujuan keterampilan / maharah yang ingin disampaikan (Sardjiyo, 2016: 501). Dalam bahasa Arab terdiri dari empat keterampilan berbahasa / maharah yang harus dikuasai yaitu istima', kalam, qira'ah, dan kitabah (Mustofa, 2011: 2). Masing-masing maharah memiliki muatan materi dan indikator ketercapaian yang berbeda-beda. Selain itu, siswa juga mempelajari kaidah tata bahasa Arab seperti kosakata dan nahwu shorof. Berdasarkan hasil penelitian dalam pendidikan bahasa Arab, bahwa peserta didiknya masih memiliki penguasaan keterampilan dan kaidah tata bahasa Arab yang rendah. Hal tersebut terjadi karena kurangnya motivasi belajar oleh peserta didik. Penyebab dari motivasi belajar yang rendah adalah karena metode pembelajaran bahasa Arab yang monoton serta terbatasnya kreativitas dan inovasi dari guru dalam menggunakan media pembelajaran bahasa Arab (Rahmat Iswanto, 2017: 144). Sehingga, solusi dalam hal ini adalah penggunaan serta pemilihan media yang tepat dan sekreatif mungkin untuk menunjang keberhasilan belajar maharahmaharah serta kaidah tata bahasa dalam pembelajaran bahasa Arab.

Dalam pengembangannya, ada beberapa jenis media pembelajaran yang dapat digunakan, namun berdasarkan penelitian yang dilakukan oleh Ahmad ibn Abd alRahman al-Samiraa'I, sebagaimana dikutip oleh Yasmaruddin Bardansyah (2008), menunjukkan bahwa tingkat penyerapan materi ilmu pengetahuan menggunakan media visual mencapai 75\%, menggunakan media audio mencapai 13\%, sedangkan menggunakan media lainnya mencapai 12\%. Suatu pembelajaran yang menggunakan media visual memberikan hasil tiga kali lebih efektif dibandingkan hanya menggunakan audio. Sementara jika dilakukan penggabungan audio dan visual, maka lebih efektif dibandingkan dengan audio saja. Oleh karena itu, media dengan audio-visual akan membantu para guru dalam menunjang pembelajaran yang efektif dan efisien.

Berdasarkan uraian yang telah dipaparkan, dapat disimpulkan bahwa peranan media tidak dapat diabaikan dan terpisahkan dari proses pembelajaran. Hal tersebut dikarenakan penggunaan media sangat bermanfaat dalam menunjang keberhasilan kegiatan belajar peserta didik. Oleh karena itu, penulis bertujuan untuk membahas mengenai media pembelajaran kurikulum bahasa Arab yang efisien, efektif, tepat, dan sesuai dengan tujuan pembelajaran kurikulum bahasa Arab itu sendiri agar 
meningkatkan motivasi belajar peserta didik tanpa membuatnya bosan. Dalam mewujudkannya, guru dituntut agar mampu dalam memilih, mengembangkan, dan mengoperasikan media secara kreatif yang sesuai dengan tujuan dari masing-masing pembelajaran. Sehingga, keberhasilan pembelajaran peserta didik dapat tercapai secara optimal.

\section{METODE PENELITIAN}

Penelitian ini merupakan studi kepustakaan yang bersumber dari berbagai literatur mengenai pengertian, tujuan, fungsi, kegunaan, aturan penentuan, dan klasifikasi media pembelajaran bahasa Arab. Cara kerja penelitian kepustakaan yaitu dengan memanfaatkan sumber referensi yang relevan untuk memperoleh data penelitian dengan membatasi kegiatan penelitian hanya pada bahan koleksi pustaka tanpa melakukan riset lapangan. Data yang diperoleh dari berbagai literatur akan digabungkan, dianalisis, dan disimpulkan sehingga mendapatkan kesimpulan mengenai media pembelajaran kurikulum bahasa Arab yang berguna untuk para akademisi.

\section{PEMBAHASAN}

\section{Media Kurikulum Bahasa Arab}

Berawal dari kata media, Nunu Mahnun (2012: 27) menyebutkan bahwa media berasal dari bahasa Latin yakni medium yang berarti perantara atau pengantar yang selanjutnya dinyatakan sebagai sarana menyalurkan informasi belajar yang akan disampaikan oleh sumber informasi kepada penerima informasi tersebut. Media atau perantara berperan sebagai penunjang aktivitas belajar mengajar yang dapat membantu pencapaian keberhasilan belajar. Menurut AECT (Association of Education and Communication Technology) yang dikutip oleh Maksudin (2006: 15), media adalah semua bentuk yang akan digunakan dalam proses penyampaian suatu informasi. Sementara menurut (National Education Association / NEA) Asosiasi Pendidikan Nasional dalam Arief S. Sadiman dkk (2006: 6) memiliki pengertian yang berbeda yaitu media adalah sarana untuk berkomunikasi, baik tercetak maupun audio-visual beserta instrumennya yang digunakan dalam kegiatan belajar mengajar. Sedangkan menurut Steffi Adam dan Muhammad Taufik Syastra (2015: 79), media pembelajaran adalah segala sesuatu yang berbentuk fisik dan teknis dalam proses belajar mengajar yang 
dapat membantu para guru, sehingga mempermudah dalam penyampaian materi pelajaran kepada siswa agar tujuan pembelajaran yang telah dirumuskan dapat tercapai.

Selain empat pendapat diatas, masih terdapat beberapa pendapat lain yang memberikan definisi yang berbeda-beda. Menurut pendapat Gerlach \& Ely yang dikutip oleh Arsyad (2016: 3), mengatakan bahwa media secara umum merupakan manusia, bahan materi, atau kejadian yang membangun kondisi agar siswa mampu memperoleh pengetahuan, keterampilan, maupun sikap. Sementara menurut Gagne yang dikutip oleh Hasibuan (2016: 24), menyatakan bahwa media adalah segala macam komponen dalam lingkungan siswa yang dapat menstimulasinya untuk belajar. Sedangkan menurut Sadiman (2008: 7), media pembelajaran adalah berbagai jenis sarana yang digunakan untuk menyalurkan informasi dari pengirim ke penerima informasi yang dapat merangsang pikiran, perasaan, minat serta perhatian penerima informasi, sehingga proses belajar dapat terjalin. Selanjutnya, menurut Hanafiah \& Suhana (2010: 59), media pembelajaran merupakan segala bentuk instrumen maupun stimulus yang disediakan oleh guru untuk membangkitkan semangat siswa agar belajar menjadi lebih cepat, tepat, mudah, dan tidak terjadinya verbalisme. Selain pendapat tersebut, Prihatin (2008: 50) mengatakan bahwa media pembelajaran adalah suatu instrumen yang dapat digunakan untuk membantu siswa dalam memahami dan memperoleh informasi yang berbentuk audio dan visual sehingga pembelajaran dapat berhasil dan bermanfaat.

\section{Tujuan Dan Fungsi Media Pembelajaran Bahasa Arab}

Fokus utama dalam hal penggunaan media adalah media tersebut berguna dalam menunjang proses belajar dan pengajaran agar suatu materi yang diberikan dapat tersampaikan secara efektif dan mudah diterima oleh peserta didik tanpa membuat peserta didik merasa bosan. Hal tersebut dikarenakan proses belajar mengajar tidak monoton, sehingga akan meningkatkan penguasaan materi pada kemahiran bahasa Arab, memberikan rasa semangat, serta menstimulasi untuk belajar hal baru pada peserta didik. Pemilihan media yang tepat dapat menjadikan peserta didik aktif dalam merespon serta mendorongnya untuk berbahasa Arab dengan benar (Nufus, 2015: 217). Penggunaan berbagai bentuk media pembelajaran merupakan wujud inovasi belajar yang berguna untuk peserta didik. 
Berdasarkan fungsinya, fungsi media dikelompokkan menjadi 2, yaitu fungsi visual dan audio visual, dengan penjelasan sebagai berikut :

a. Fungsi Media Visual

Menurut Levie dan Lentz dalam Arsyad (2007: 16-17), berpendapat bahwa media visual sebagai alat bantu proses belajar mengajar, memiliki 4 fungsi sebagai berikut ;

1) Kognitif : memberikan kemudahan pada peserta didik dalam memahami materi pembelajaran yang disampaikan.

2) Atensi : media disini dapat menarik perhatian siswa pada saat proses belajar mengajar, hal itu dapat membuat siswa benar-benar fokus pada materi pembelajaran.

3) Kompensatoris : memudahkan siswa yang lamban dalam menerima materi pembelajaran dengan mengakomodasi siswa peserta didik yang lamban tersebut.

4) Afektif : media tersebut dapat membuat peserta didik gembira, bahagia, dan senang pada saat proses pembelajaran berlangsung tanpa adanya kejenuhan maupun rasa bosan.

b. Fungsi Media Audio Visual

Fungsi media audio-visual menurut Hafni dalam Abdul Wahab Rosyidi (2009: 29-32) adalah tidak hanya menyampaikan informasi, namun juga memperlancar proses datangnya suatu informasi yang lamban kepada penerima sehingga proses datangnya informasi tetap lancar tanpa suatu hambatan. Adapun manfaat dari penggunaan media audio-visual berdasarkan fungsinya yaitu sebagai berikut :

1) Fungsi media disini dapat menjadi suatu titik dimana peserta didik dapat memfokuskan dirinya masing-masing kepada media yang digunakan, hal itu terjadi ketika sudah menarik perhatian peserta didik, yang merupakan satu langkah dimana peserta didik dapat serius mengikuti pelajaran.

2) Fungsi selanjutnya yaitu membuat peserta didik mampu memahami suatu materi dengan tidak merasa kesulitan dengan melihat teks yang panjang 
dan susah dicerna bahasanya, sehingga sulit ada gambaran untuk memahami materi tersebut.

3) Setelah itu dalam lingkup media pendengaran dan penglihatan, membuat materi yang diberikan menjadi mudah dipahami peserta didik.

4) Setelah itu memberikan sesuatu yang mungkin menjadi ada, misal jika pada kurikulum bahasa Arab akan dijelaskan materi istima' wal kalam maka guru bisa memperdengarkan suara teks yang suara dari asli natif orang Arab asli, tanpa perlu datang ke Arab atau mendatangkan syekh dari sana.

5) Selain itu, dengan merasakan dan mengalami suatu hal misal bermain peran dengan menjadi orang yang sedang berpergian dan membawa alatalat bahkan kostum penunjang (dalam teks hiwar) hal tersebut membuat siswa lebih memahami dan mengahafal teks yang biasa ditanyakan ketika berpergian sesuai teks hiwar tersebut.

\section{Kegunaan Media Pembelajaran Bahasa Arab}

Menurut pandangan Sadiman dalam Tafonao (2018: 107-108), media pembelajaran jika dilihat secara umum memiliki beberapa kegunaan, yaitu sebagai berikut :

1) Mengatasi keterbatasan yang dimiliki peserta didik dari segi kemampuan indera, waktu, dan ruang.

2) Teks yang panjang atau berbelit-belit yang harus dipahami dan dihafal peserta didik, dapat diatasi dengan memperjelas penyajian materinya agar mudah dipahami peserta didik.

3) Perilaku peserta didik yang pasif dapat diatasi dengan cara memanfaatkan penggunaan media yang tepat dan bervariasi.

\section{Klasifikasi Media dalam Pembelajaran Bahasa Arab}

Media pembelajaran Bahasa arab dapat diklasifikasikan menjadi beberapa bagian, diantaranya :

1. Dilihat dari segi fungsi yang berhubungan dengan alat penginderaan.

Menurut Sanjaya (2009: 211), dilihat dari segi sifatnya, media dibagi menjadi tiga pokok pembahasan yaitu alat untuk penunjang sesuatu yang dilihat, 
alat penunjang sesuatu yang didengar, dan alat penunjang sesuatu yang dilihat maupun yang didengar dan media ini adalah media yang kerap kali dipakai.

1) Alat untuk penunjang sesuatu yang dilihat / Visual

Menurut Sudjana dan Ahmad Rivai (2011: 2), media visual diklasifikasikan menjadi 2 macam, yaitu media yang memerlukan bantuan cahaya dan media yang tidak memerlukan bantuan cahaya maupun tenaga listrik ketika dalam menjalankannya, atau disebut proyeksi dan non-proyeksi.

2) Alat untuk penunjang sesuatu yang didengar / audio

Nana Sudjana dan Ahmad Rivai dalam Arsyad (2009: 45), mengemukakan fungsi media audio adalah untuk melatih segala kegiatan yang berhubungan dengan keterampilan mendengarkan /istima'.

2. Dilihat dari pandangan dalam berbahasa arab dan kemahirannya, media dapat dikelompokan dalam beberapa bagian sebagai berikut :

1) Alat bantu proses belajar-mengajar upaya meningkatkan kosakata / mufrodat dalam berbahasa Arab.

Siti Hasnah (2015: 199) mengemukakan bahwa dari beraneka ragam alat bantu, ternyata media gambar merupakan alat bantu yang paling efektif dan efisien untuk mengajarkan kosakata dalam bahasa Arab. Berikut adalah alat bantu yang dapat membantu meningkatkan kosakata dalam berbahasa Arab :

a. Benda-benda tiruan yang kegunaannya sebagai pengganti ketika dilihat dari konsep ruang dan waktu tidak memungkinkan.

b. Kartu bergambar yang dapat menjadi perantara media belajar mufrodat, ketika ingin menunjukkan bahasa Arabnya mobil maka guru mengeluarkan dan menunjukkan kartu bergambar mobil tersebut, biasanya disertakan Arab dan terjemahannya.

c. Video Mufrodat, yang didalamnya berisikan sekumpulan mufrodat yang dikelompokkan dari berbagai jenis. Terkait hal tersebut, ada suatu penelitian yang telah menggunakan media video atau audio visual untuk pembelajaran mufrodat yaitu penelitian dari Siti Hajar Rahmayanti (2014: 101), dengan hasil penelitian menunjukkan bahwa penerapan 
media audio visual dapat meningkatkan penguasaan mufrodat pada siswa kelas V SDIT Al-Misbah Sumobito Jombang.

d. Buku Mufrodat

Mufrodat disini, yang didalamnya dikhususkan untuk membahas macam - macam kumpulan kosakata bahasa Arab yang dikelompokkan dari berbagai jenis.

2) Alat bantu proses belajar-mengajar Nahwu-shorof

Agar menjadi kalimat yang sempurna dibutuhkan aturan bahasa, tujuan adanya pembelajaran nahwu shorof ini adalah agar kalimat lebih mudah dipahami karena disusun secara benar. Berikut alat perantara yang menunjang proses belajar nahwu-shorof sebagai berikut :

a. Sobekan kertas acak

Strip story berarti potongan / sobekan kertas dalam teks maupun film. Media ini diperkenalkan oleh prof. R.E. gibson dalam majalah TESL Quarterly Vol. 9 No. 2 tahun 1978, yang kemudian dikembangkan lebih lanjut oleh Mary Ann dan John Boyd dalam TOSEL Newsletter dan dijelaskan dengan pengalaman oleh Carol Lamelin di Majalah yang sama yaitu pada tahun 1979. Pembelajaran bahasa dengan media strip story menggunakan pendekatan komunikatif yang bertujuan agar mempermudah peserta didik dalam berkomunikasi menggunakan bahasa Arab (Afandi, 2009: 75). Sejalan dengan hal tersebut, pada penulisan ini digunakan media kertas yang dipotong, per potongan untuk satu kata baik itu fi'il, isim maupun harf. Setelah itu peserta didik disuruh menggabungkan beberapa kata tadi menjadi sebuah kalimat yang baik dan benar.

b. Kardus kecil berbentuk segi empat 3 dimensi

Pada setiap sisi kardus itu diberi satu kosa kata yang terdiri dari fi'il , fa'il, maf'ul atau bisa juga ditambah dengan keterangan. Setelah itu siswa diperintah untuk mengamati kata-kata tersebut dan menggabungkannya menjadi sebuah kalimat yang ditulis dikertas atau maju ke depan untuk menulis di papan tulis.

c. Papan Triplek berkantong 
Media papan kantong adalah media yang bisa dibuat dengan menggunakan papan triplek / karton tebal yang ukurannya kira-kira 90 cm x $60 \mathrm{~cm}$ dan terdapat deretan kantong. Manfaat dari penggunaan media ini adalah mengatasi keterbatasan ruang, waktu, serta tenaga, menimbulkan semangat belajar siswa, dan meningkatnya interaksi antara murid dan sumber belajar (Layyinatus Shifa dan Aquami, 2015: 3).

3) Alat bantu proses belajar mengajar dalam kemahiran Berbahasa Arab

Kemahiran berbahasa Arab terdiri dari 4 kemahiran, yaitu kemahiran mendengarkan teks Arab yang berupa disuarakan atau diungkapkan dengan seksama atau disebut al-istima', kemahiran berbicara bahasa Arab atau disebut al-kalam, kemahiran dalam memahami suatu teks berbahasa Arab dengan membacanya atau disebut al-qira'ah, kemudian yang terakhir adalah kemahiran untuk mengungkapan suatu gagasan maupun ide atau karangan diri menggunakan bahasa Arab menggunakan teknik menulis atau al-kitabah.

Banyak sekali media yang dapat digunakan, hal itu sesuai juga dengan bagaimana guru membuat konsep sekreatif mungkin dengan ide-idenya. Misal dengan bantuan poster bergambar atau benda disekitar, guru memperlihatkan beberapa poster tersebut dan siswa dianjurkan untuk menceritakan, mengarang, dan membuat kalimat mengenai poster tersebut menggunakan bahasa Arab atau yang disebut insya'. Selain itu, juga bisa dengan cara guru menunjuk benda yang ada disekitarnya didalam kelas seperti kursi, lemari, jam, kemudian siswa disuruh membuat karangan bebas mengenai benda yang ditunjuk tersebut.

Media lainnya yang bisa digunakan yaitu dengan media TTS yang merupakan suatu permainan kata yang berisi pertanyaan untuk jawaban vertikal maupun horizontal. TTS tersebut bisa disesuaikan dengan materi yang dijelaskan. Misal dengan pertanyaan mencari sinonim maupun antonim dari beberapa mufrodat. Hal tersebut diperkuat dengan pemaparan Umi Hanifah (2014: 38-39), bahwa TTS dapat digunakan pada pembelajaran bahasa Arab khususnya pada maharah kitabah, karena penerapan TTS bermanfaat untuk melatih siswa dalam menulis huruf Arab secara lepas serta melatih penguasaan mufrodat. 
Media yang lainnya yang dapat digunakan misalnya dengan film atau video cerita pendek. Yaitu dengan cara video itu diputarkan dan diperdengarkan kepada peserta didik, selanjutnya ketika video sudah berakhir guru menanyakan hal yang terkait mengenai video tersebut dengan $5 \mathrm{~W}+1 \mathrm{H}$ yang terdapat dicerita itu, atau bisa juga dengan guru menugaskan untuk menceritakan kembali isi ataupun poin-poin yang ada dalam cerita tersebut. Penerapan media film atau video cerita pendek telah diteliti sebelumnya oleh Laelina Cahyani (2015: 80-81), dengan hasil penelitian menunjukkan bahwa penggunaaan media film dalam pembelajaran bahasa Arab dapat meningkatkan keterampilan berbicara.

Selain media yang telah disebutkan tadi, media lainnya yang bisa digunakan adalah benda tiruan, guru menunjukkan beberapa benda yang akan dijadikan media, kemudian guru memperlihatkan satu benda kepada peserta didik untuk mendeskripsikannya. misalnya, dengan cara lisan, dimulai dari nama sampai karakteristiknya meliputi bentuk dan warnanya apa, teksturnya bagaimana dan lain-lain.

Kemudian, media selanjutnya adalah dengan penggunaan jam, dengan cara guru memutar jarum jam dan memberhentikannya kesalah satu angka, kemudian menanyakan kepada peserta didik itu menunjukkan jam berapa, kemudian peserta didik menjawabnya menggunakan bahasa Arab. Atau bisa juga bertanya jam berapa peserta didik bangun, kapan pembelajaran sekolah dimulai, kapan pembelajaran sekolah usai, dan sebagainya.

Lalu untuk tahap berbicara yang masih tahap pemula dengan menirukan, dapat menggunakan media kartu yang berisi gambar dan mufrodatnya, dengan cara guru menunjukkan kartu gambar tersebut pada peserta didik kemudian mengucapkannya, setelah itu peserta didik menirukan.

\section{KESIMPULAN}

Media pembelajaran bahasa Arab yaitu segala sesuatu yang digunakan selama proses belajar dan pengajaran berlangsung, yang berguna sebagai penunjang dalam memperoleh dan menyampaikan materi bahasa arab kepada peserta didik sesuai dengan kurikulum mata pelajaran bahasa arab. Berdasarkan fungsinya, media 
dikelompokkan menjadi dua, yaitu fungsi visual dan audio visual. Fungsi media visual terdiri dari fungsi Kognitif, Atensi, Kompensatoris, dan Afektif. Sedangkan media audio-visual dapat berfungsi menjadi suatu titik dimana peserta didik dapat memfokuskan dirinya masing-masing kepada media yang digunakan, sehingga peserta didik dapat serius mengikuti pelajaran. Fungsi selanjutnya yaitu membuat peserta didik mampu memahami suatu materi dengan tidak merasa kesulitan dalam melihat teks yang panjang dan bahasa yang susah dicerna. Selain itu, dalam lingkup media pendengaran dan penglihatan, media audio visual membuat materi yang diberikan menjadi mudah dipahami peserta didik. Media audio visual juga memberikan sesuatu yang mungkin menjadi ada. Kemudian dengan penerapan media audio visual seperti bermain peran pada suatu materi dapat membuat siswa lebih memahami materi tersebut.

Media pembelajaran jika dilihat secara umum memiliki beberapa kegunaan, pertama, dapat mengatasi keterbatasan dari segi kemampuan indera, waktu, dan ruang. Kedua, dapat mengatasi teks yang panjang atau berbelit-belit dengan memperjelas penyajian materinya agar mudah dipahami peserta didik. Ketiga, dapat mengatasi perilaku peserta didik yang pasif dengan menggali beberapa informasi sesuai kebutuhannya dengan mudah, membangkitkan rasa semangat dalam belajar, Memungkinkan adanya hubungan secara langsung antara siswa-siswi dengan lingkungannya dan dengan suatu hal yang benar-benar nyata, serta mendukung siswasiswi untuk belajar mandiri sesuai keinginan dan kemampuannya.

Klasifikasi media dalam pembelajaran bahasa Arab dapat dilihat dari dua segi yaitu segi fungsi yang berhubungan dengan alat penginderaan serta pandangan dalam berbahasa arab dan kemahirannya. Dilihat dari segi fungsi yang berhubungan dengan alat penginderaan, media dibagi menjadi alat penunjang visual, alat penunjang audio, dan alat penunjang audio visual. Sedangkan, dilihat dari pandangan dalam berbahasa arab dan kemahirannya, media dapat dikelompokan menjadi alat bantu proses belajarmengajar mufrodat, alat bantu proses belajar-mengajar Nahwu-shorof, dan alat bantu proses belajar mengajar dalam kemahiran berbahasa Arab yang terdiri dari alat bantu istima', qiro'ah, kitabah, dan kalam dalam proses belajar mengajar. 


\section{Daftar Pustaka}

Adam, Steffi dan Muhammad Taufik Syastra. Pemanfaatan Media Pembelajaran Berbasis Teknologi Informasi Bagi Siswa Kelas X SMA Ananda Batam. CBIS Journal, Vol. 3, No. 2, hlm 79. 2015.

Afandi, Samsul. Penggunaan Teknologi Pengajaran Bahasa untuk Meningkatkan Keterampilan Siswa dalam berbahasa Arab. Makalah, hlm 75. 2009.

Ahid, Nur. Konsep dan Teori Kurikulum dalam Dunia Pendidikan. ISLAMICA, Vol. 1, No. 1, hlm 18. 2006.

Aminudin. Media Pembelajaran Bahasa Arab. Al-Munzir, Vol. 7, No. 2, hlm 16. 2014.

Arsyad, Azhar. Media Pembelajaran. Jakarta : Raja Grafindo. 2007.

Arsyad, Azhar. Media Pembelajaran. Jakarta: Raja Grafindo Persada Rineka Cipta. 2014.

Bardansyah, Yasmaruddin.. Urgensi Penciptaan Lingkungan Berbahasa Asing, Makalah. 2008.

Cahyani, Laelina. Upaya Meningkatkan Kemahiran Berbicara (Al-Kalam) Melalui Media Film dalam Pembelajaran Bahasa Arab Di SMP Muhammadiyah 2 Depok Sleman Tahun Ajaran 2014/2015 (Tidak diterbitkan). Yogyakarta : Sarjana Pendidikan Bahasa Arab UIN Sunan Kalijaga, hlm 80-81. 2015.

Ferdiani, Jenny. Efektivitas Pembelajaran Kosakata Bahasa Jepang dengan Menggunakan Media Permainan Domikado (Tidak Diterbitkan). Bandung : Sarjana Pendidikan Bahasa Jepang UPI. 2012.

Hadi, Abdul. Arabia. Jurnal Pendidikan Bahasa Arab, Vol. 3, No.2, , hlm 5. 2011.

Hamalik, Oemar. Kurikulum dan Pembelajaran. Jakarta: Bumi Aksara. 2007.

Hamalik, Oemar. Manajemen Pengembangan Kurikulum. Bandung : PT Remaja Rosdakarya. 2010.

Hanafiah dan Suhana. Konsep Strategi Pembelajaran. Bandung: PT Refika Aditama. 2010.

Hanifah, Umi. Media Pembelajaran Bahasa Arab. Surabaya : UINSA Press. 2014.

Hasibuan, Nasruddin. Implementasi Media Pembelajaran dalam Pendidikan Agama Islam. Jurnal Darul 'Ilmi, Vol. 4, No. 1, hlm 24. 2014.

Hasnah, Sitti. Pembelajaran Kosakata (Mufradat) Bahasa Arab melalui Media Gambar Untuk Meningkatkan Minat Belajar Mahasiswa pada Jurusan PAI Fakultas Tarbiyah IAIN Palu. Istiqra : Jurnal Penelitian Ilmiah, Vol. 3, No. 1, hlm 199. 2015. 
ATHLA : Journal of Arabic Teaching, Linguistic And Literature, 1, (1), 2020

Hidayat, Sholeh.. Pengembangan Kurikulum Baru. Bandung : PT Remaja Rosdakarya. 2017. Iswanto, Rahmat. Pembelajaran Bahasa Arab dengan Pemanfaatan Teknologi. Arabiyatuna, Jurnal Bahasa Arab,Vol 1, No 2, hlm 144. 2017.

Jonathan, Sarwono. Metode Penelitian Kuantitatif dan Kualitatif. Yogyakarta : Graha Ilmu. 2006.

Mahnun, Nunu. Media Pembelajarab (Kajian terhadap Langkah-Langkah Pemilihan Media dan Implementasinya dalam Pembelajaran). Jurnal Pemikiran Islam, Vol. 37, No.1, hlm 27. 2012.

Maksudin. Media Pembelajaran Bahasa Arab. Al-'Arabiyah, Vol. 2, No. 2, hlm 15. 2006.

Mustofa, Syaiful. Strategi Pembelajaran Bahasa Arab Inovatif. Malang: UIN Malik Press. 2011.

Nufus, Hayati. Pembelajaran Insya (Kitabah) dengan Media Strip Story. Jurnal Horizon Pendidikan, Vol. 10, No. 2, hlm 217. 2015.

Nuha, Ulin. Ragam Metodologi dan Media Pembelajaran Bahasa Arab. Yogyakarta : Diva Press. 2016.

Prihadi. Media Pembelajaran, Media Pembelajaran Bahasa Indonesia. Jakarta : Direktorat Jendral Pendidikan Lanjutan Pertama KEMENDIKNAS, hlm 14-15. 2010.

Prihatin, Eka. Guru Sebagai Fasilitator. Bandung: Karsa Mandiri Persada. 2008.

Rahmayanti, Siti Hajar. Penerapan Media Audio Visual Untuk Meningkatkan Penguasaan Mufradat pada Mata Pelajaran Bahasa Arab Bagi Siswa Kelas V SDIT Al-Misbah Sumobito Jombang (Tidak diterbitkan). Malang : Sarjana Pendidikan Madrasah Ibtidaiyah UIN Maulana Ibrahim Malang, hlm 101. 2014.

Rosyidi, Abdul Wahab. Media Pembelajaran Bahasa arab. Malang : UIN Malang Press. 2009.

Sadiman, Arief S. dkk. Media Pendidikan. Jakarta: PT Raja Grafindo Persada. 2006.

Sadiman, Arief S. Media Pembelajaran: Pengertian, Pengembangan dan Pemanfaatannya. Jakarta: Raja Grafindo Persada. 2008.

Sanjaya, Wina. Penelitian Tindakan Kelas. Jakarta : Kencana. 2009.

Sardjiyo. Optimalisasi Penggunaan Media Pembelajaran Sebagai Wujud Inovasi Belajar yang Bermakna dalam Pengembangan Karakter Peserta Didik. Prosiding Temu Ilmiah Nasional Guru (TING) VIII, hlm 501. 2016. 
ATHLA : Journal of Arabic Teaching, Linguistic And Literature, 1, (1), 2020

Shifa, Layyinatus dan Aquami. Penggunaan Media Papan Kantong Dalam Meningkatkan Hasil Belajar Siswa Kelas III Materi Surat Pendek Pada Mata Pelajaran Al-Qur'an Hadist Di MI Al-Amanah Baruharjo Kec Buay Madang Timur Kab Oku Timur. Ta'dib : Jurnal Pendidikan Islam, Vol 1, hlm 3. 2015.

Sudjana, Nana. Pembinaan dan Pengembangan Kurikulum di Sekolah (cet.ke-6). Bandung: Sinar Baru Algesindo.2008.

Sudjana, Nana dan Ahmad Rivai. Media Pengajaran. Bandung: Sinar Baru Algensindo.2011.

Sulaeman. Implementasi Kurikulum 2013 dalam Pembentukan Karakter Peduli Lingkungan Siswa SMA Negeri 6 Kendari (Tidak Diterbitkan). Kendari : Sarjana Pendidikan Agama Islam IAIN Kendari, hlm 12. 2016.

Suryani, Nunuk dan Leo Agung. Strategi Belajar Mengajar. Yogyakarta : Penerbit ombak. 2012.

Tafonao, Talizaro. Peranan Media Pembelajaran dalam Meningkatkan Minat Belajar Mahasiswa. Jurnal Komunikasi Pendidikan, Vol. 2, No. 2, hlm 107-108. 2018.

Umroh, Ida Latifatul. Tape Recorder sebagai Media Pembelajaran untuk Meningkatkan Keterampilan Menyimak. DAR EL-ILMI : Jurnal Studi Keagamaan, Pendidikan, dan Humaniora, Vol. 5, No. 1, hlm 17. 2018. 
ATHLA : Journal of Arabic Teaching, Linguistic And Literature, 1, (1), 2020

64 | Damar Gemilang, Hastuti Listiana : Teaching Media in the Teaching of .... 